\title{
Optimalisasi Teknologi Komunikasi Informasi Command Center Bagi Efektifitas Tenaga Kesejahteraan Sosial Kecamatan
}

\author{
Rio Febriannur Rachman \\ Institut Agama Islam Syarifuddin Lumajang \\ Email : riofrachman21@gmail.com
}

\begin{abstract}
Surabaya has many problems with Social Welfare Problems (Penyandang Masalah Kesejahteraan Sosial or PMKS). The existence of the District Social Welfare Workers (Tenaga Kesejahteraan Sosial Kecamatan or TKSK) or social volunteers formed by the Ministry of Social Affairs has a central role in eradicating this problem. In 2016, when the Command Center 112 was launched by the Surabaya City Government, with the use of communication and information technology, TKSK was also given access to receive information from there. Interestingly, TKSK in each district has a good relationship with those in other districts. So, they can help each other when running errands.
\end{abstract}

Keywords: Technology, Communication, Volunteers, Surabaya City Government

\section{PENDAHULUAN}

Sebagai salah satu kota besar di Indonesia (Santoso, 2009: Arfiadi, Yoyong, and Iman Satyarno, 2013), Surabaya memiliki banyak persoalan Penyandang Masalah Kesejahteraan Sosial (PMKS).Keberadaan Tenaga Kesejahteraan Sosial Kecamatan (TKSK) yang dibentuk oleh Kementerian Sosial memiliki peran sentral dalam pemberantasan persoalan ini (Pramadya, 2016: Vinda, 2017). meski demikian, TKSK akan lebih optimal tugasnya bila terus berkoordinasi dengan Pemerintah Kota Surabaya. Khususnya, Dinas Sosial. Meski memang, koordinasi intensif juga harus dilaksanakan dengan kelurahan/kecamatan, dinas kesehatan, dan Organisasi Perangkat Daerah (OPD) lainnya.

Penangan PMKS di kota besar seperti Surabaya, kerap menemui persoalan (Pranowo \& Hidayatullah, 2018). Antara lain, alat komunikasi dan informasi yang bisa menunjukkan kondisi lapangan secara kongkret. Sehingga, bila ada persoalan di satu 
titik, petugas bisa datang ke tempat itu secepat mungkin. Juga, alat transportasi untuk mendukung mobilitas petugas. Baik untuk mobilitas dalam kota, maupun ke luar kota saat mengantarkan PMKS luar kota kembali ke daerah asal. Kesigapan dan kemampuan petugas Pemerintah Kota maupun TKSK selama 24 jam non stop untuk ikut mengurai masalah PMKS. Sebab, persoalan PMKS di kota besar tidak mengenal jam kerja. Problem yang ada kerap datang secara beruntun sebelum problem sebelumnya selesai.Pantauan terhadap PMKS yang sudah pernah dibantu dan difasilitasi, namun setelah pendampingan selesai, dia kembali terjerumus ke masalah yang sama.

Pada 2010, Wali Kota Surabaya Tri Rismaharini (Detik Surabaya, 2017) membaca sejumlah masalah yang timbul terkait pelayanan publik bersama TKSK sebagai tantangan yang mesti dihadapi. Maka itu, muncullah inovasi untuk penguatan sistem komunikasi dan informasi. Misalnya, dengan pengadaan Handy Talky bagi para TKSK. Sehingga, bisa berkomunikasi dengan petugas Pemerintah Kota dari berbagai OPD lainnya di lapangan.

Pada 2016, saat Command Center 112 diluncurkan (Makhdar, 2018: Purwantoro, 2019), TKSK juga diberi akses untuk bisa menerima informasi dari sana. Segala keluhan dan persoalan PMKS di tingkat kecamatan, yang dianggap bisa turut diselesaikan atau difasilitasi oleh TKSK, akan langsung disampaikan pada mereka. Yang menarik, TKSK di setiap kecamatan memiliki hubungan baik dengan yang ada di kecamatan lainnya. Jadi, mereka bisa saling membantu saat menjalankan tugas.

Wali Kota Tri Rismaharini juga mengalokasikan anggaran untuk pengadaan mobil patroli di OPD. Mobil-mobil itu bisa dipakai TKSK untuk mobilitasnya bersama PMKS yang tengah ditangani. Baik di dalam kota, maupun ke luar kota (Enciety.Co, 2017). Khususnya, dalam upaya pemulangan TKSK yang ber-KTP luar kota. Pengadaan ambulan di Dinas Sosial maupun Dinas Kesehatan juga dilakukan. Sebab, kebutuhan alat transportasi ini bisa dibilang urgen. Khususnya, bagi mobilitas PMKS yang memiliki permasalahan kesehatan.

Adapun persoalan tentang pantauan berkesinambungan pada para PMKS yang sudah pernah dibantu, TKSK Surabaya berinisiatif untuk membuat form khusus 
guna pengarsipan. Dengan demikian, data PMKS yang sudah pernah terjaring bisa terus dipantau. PMKS yang sudah terjaring karena satu kasus/permasalahan, lantas terjaring kembali, penanganannya pasti beda dengan yang baru terjaring. Misalnya, ada satu PMKS yang terjaring karena dia tidak punya pekerjaan dan mengemis, dia pun diberi pelatihan oleh OPD di Pemerintah Kota. Lantas, dia suatu waktu, dia terjaring lagi karena kembali mengemis. Maka, penanganannya pasti berbeda, karena berarti masalahnya tidak hanya soal pekerjaan. Bisa jadi, ada masalah mentalitas di sana, ataumasalah lingkungan sekitar yang memengaruhi.

\section{PEMBAHASAN}

\section{Komunikasi Publik Bagi Masyarakat Informasi}

Komunikasi Publik adalah salah satu jenis atau bentuk komunikasi, selain komunikasi intrapribadi (intrapersonal communication), komunikasi antarpribadi (interpersonal communication), komunikasi kelompok (group communcation), komunikasi organisasi (organization communication), dan komunikasi massa (mass communication). Komunikasi Publik dikenal dengan banyak nama/istilah -urusan publik (public affairs), informasi publik (public information), dan hubungan publik (public relation) atau humas (hubungan masyarakat).

Secara praktis, pengertian komunikasi publik digambarkan dengan baik oleh situs School of Communication American University berikut ini: It's at the heart of our economy, society, and politics. Studios use it to promote their films. Politicians use it to get elected. Businesses use it to burnish their image. Advocates use it to promote social causes.It's a field built on ideas and images, persuasion and information, strategy and tactics. No policy or product can succeed without a smart message targeted to the right audience in creative and innovative ways. The ability to communicate this way - to communicate strategically - is what our programs are all about.

Komunikasi publik ini erat kaitannya dengan kebijakan publik yang dicetuskan pemerintah (Dijkzeul \& Moke, 2005). Artinya, pemerintah harus pandai membuat media komunikasi dan penyebaran informasi agar kebijakannya menyentuh semua lapisan masyarakat. Keberadaan Command Center 112 adalah salah satu kebijakan 
publik yang mengoptimalkan teknologi komunikasi dan informasi, demi penguatan komunikasi dan pelayanan publik di Surabaya.

Sekalipun Komunikasi Publik sering pula disebut sebagai komunikasi massa (mass communication), tetapi sesungguhnya berbeda. Komunikasi massa lebih spesifik, yakni komunikasi melalui media massa (communicating with media). Komunikasi publik lebih luas daripada komunikasi massa. Komunikasi massa "hanya" menggunakan media massa, seperti suratkabar, majalah, website, radio, dan televisi. Komunikasi publik lebih luas lagi. Selain menggunakan media massa, komunikasi publik juga menggunakan e-mail, blog, jejaring sosial seperti Facebook dan Twitter, Yahoo Messengger, Handphone (SMS), dan medium lain yang bisa menjangkau khalayak luas/banyak seperti aksi demo, seminar, diskusi, dan sebagainya (Watie, 2016).

Komunikasi publik merupakan kombinasi antara hubungan dengan media masa (media relations), jangkauan komunitas (community outreach), komunikasi krisis (crisis communication), relasi pelanggan (customer relations), perencanaan acara (event planning), komunikasi risiko (risk communication). Komunikasi Publik adalah penyampaian pesan (message), berupa ide atau gagasa, informasi, ajakan, dan sebagainya kepada orang banyak.

Kecanggihan teknologi komunikasi saat ini membuat semua orang bisa melakukan komuniksi publik. Sekadar contoh, jika kita memposting sebuah komentar pada sebuah kolom komentar yang dapat diakses banyak orang, maka itu Komunikasi Publik. Jika kita mengatakan sesuatu di ruang publik yang dapat diakses banyak orang, maka itu Komunikasi Publik.

Ciri utama Komunikasi Publik adalah berisi pesan yang penting diketahui publik - dikenal dengan Informasi Publik. Yang dikomunikasikan menyangkut urusan publik (Public Affairs) atau yang diharapkan menggugah orang banyak. Sebagai contoh, lembaga-lembaga survei selalu mengumumkan hasil surveinya kepada media massa, pengamat yang tidak diwawancara media mengirimkan komentarnya tentang isu aktual kepada wartawan, dan sebagainya. 
Information society atau masyarakat Informasi adalah sebuah istilah yang digunakan untuk mendeskripsikan sebuah masyarakat dan sebuah ekonomi yang dapat membuat kemungkinan terbaik dalam menggunakan informasi dan teknologi komunikasi baru (new information and communication technologies(ICT's)).

Dalam masyarakat informasi orang akan mendapatkan keuntungan yang penuh dari teknologi baru dalam segala aspek kehidupan:Di tempat kerja, di rumah dan tempat bermain. Contoh dari ICT's adalah: ATM untuk penarikan tunai dan pelayan perbankan lainnya, telepon genggam(handphone), teletext television, faxes dan pelayan informasi seperti juga internet, e-mail, mailinglist, serta komunitas maya (virtual community) lainnya.

Pengertian lain dari informastion society atau masyarakat informasi adalah suatu keadaan masyarakat dimana produksi, distribusi dan manipulasi suatu informasi menjadi kegiatan utama. Jadi dapat dikatakan bahwa pengolahan informasi adalah inti dari kegiatan Teknologi baru ini memiliki implikasi untuk segala aspek dari masyarakat dan ekonomi kita, teknologi mengubah cara kita melakukan bisnis, bagaimana kita belajar, bagaimana kita menggunakan waktu luang kita. Command Center 112 yang bisa mengefisiensikan tugas TKSK di Surabaya adalah bentuk penerapan komunikasi publik di era masyarakat informasi seperti sekarang ini.

\section{Implementasi Kebijakan Publik di Era Media Baru}

Anderson (1984) dalam Public Policy-Making mengutarakan, kebijakan publik dilakukan oleh pemerintah secara resmi dan dijalankan oleh struktur-struktur di dalam pemerintahan itu. Anderson menyimpulkan bahwa kebijakan publik adalah tindakan yang memunyai tujuan tertentu yang diikuti dan dilaksanakan oleh seorang pelaku atau sekelompok pelaku guna memecahkan suatu masalah tertentu. Kebijakan publik bisa diartikan sebagai tatanan atau aturan mengenai tindakantindakan tertentu, untuk tujuan tertentu, yang dikoordinasikan oleh pemerintah, demi memajukan masyarakat umum.

Pelaksanaan program Command Center 112 yang dihubungkan dengan tugastugas TKSK adalah bentuk implementasi kebijakan publik (Afifa, 2017). Khususnya, di 
era media baru, yang kerap dikaitkan dengan eksistensi internet. Command Center 112 memunyai korelasi dengan internet, paling tidak di aspek promosi dan penyiaran informasinya. Implementasi kebijakan publik di era media baru, yang dirumuskan dalam pelaksanaan program Command Center 112 dihubungkan dengan tugas-tugas TKSK, bisa diukur melalui kondisi sebelum dan sesudah program ini dijalankan.

Keluaran konkret dari program ini adalah penyediaan alat komunikasi dan akses TKSK untuk memantau informasi di Command Center 112 milik Pemerintah Kota Surabaya. Pengadaan Handy Talkie. Penyediaan alat transportasi berupa ambulan dan mobil angkut di Dinas Sosial dan dinas-dinas lain yang siap dipakai kapan pun oleh TKSK untuk membawa PMKS.Koordinasi secara berkelanjutan antara TKSK dan petugas Pemerintah Kota dari berbagai Organisasi Perangkat Daerah untuk memastikan problem PMKS di Surabaya selalu terpantau.

Ada banyak manfaat yang bisa dipetik dengan munculnya inovasi ini. TKSK bisa lebih sigap dan cepat dalam menyelesaikan masalah. Koordinasi dapat berjalan dengan lancar. Kebutuhan akses transportasi dan solusi aplikatif di lapangan dapat diperoleh dengan cepat. Sebab, dengan keterbukan komunikasi antara TKSK dengan Dinas Sosial dan OPD lain di Pemerintah Kota, kebutuhan PMKS bisa langsung disampaikan. Dengan demikian, permasalahan bisa langsung diselesaikan.

Koordinasi antara Dinas Sosial dan OPD di Pemerintah Kota, yang semua terkoneksi melalui Command Center 112, dengan para TKSK membuat penangan terhadap PMKS bisa menyeluruh dan cepat tertangani. Komunikasi dan informasi yang cepat tersalurkan, bisa membuat masing-masing pihak mengetahui masalah yang dihadapi, sekaligus mencarikan solusi secepat mungkin.

Pekerjaan Pemerintah Kota dan TKSK dalam memberantas PMKS dijalankan tanpa melihat jam kerja. Selama 24 jam non stop, baik TKSK maupun aparat pemerintahan selalu stand by menghadapi masalah PMKS yang mungkin terjadi kapan saja. TKSK mengatasi permasalahan secara menyeluruh. Sebagai contoh, bila ada satu PMKS terjaring, akan ditelaah persoalan dia dari segala aspek. Untuk kemudian, dicarikan solusinya dengan detail. Dinilai, OPD mana saja yang perlu turun tangan untuk memberikan solusi. Lantas, dikoordinasikan. 
Saat ini, TKSK memiliki manajemen pelayanan klien yang komprehensif. Data klien yang sudah pernah terjaring maupun yang baru terjaring sudah dikantongi. Jadi, bila yang bersangkutan tersandung masalah yang sama, berarti ada pangkal persoalan yang lebih kompleks dalam dirinya. Maka itu, penyelesain lanjutan akan lebih kompleks lagi. Artinya, optimalisasi fungsi TKSK sudah dijalankan. Meski memang, akan terus dikembangkan dan ini merupakan tugas semua pihak. Sebelum adanya Command Center 112 yang terkoneksi dengan TKSK, komunikasi dan mobilitas TKSK belum maksimal. Pengarsipan riwayat PMKS yang sudah terjaring belum ada. Setelah adanya program ini, komunikasi dan mobilitas TKSK lebih maksimal. Penanganan bisa lebih cepat dan kelengkapan informasi membuat penanganan lebih sempurna karena sudah bisa membaca apa kebutuhan di lapangan. Pengarsipan riwayat PMKS sudah dilakukan sehingga penanganan bisa lebih menyeluruh, tuntas, dan tepat sasaran. Karena, ada pendataan secara online melalui fitur-fitur yang mendukung di Command Center 112.

\section{Sinergitas dalam Pelayanan Publik}

Program Command Center 112 yang dikoneksikan dengan para TKSK di Surabaya berjalan secara bertahap dan terarah. Pada 2010, gagasan muncul. Dilakukan perencanaan inovasi.Dilakukan pengadaan alat komunikasi bagi TKSK berupa Handy Talky.Dilakukan pengadaan alat transportasi untuk mendukung mobilitas TKSK. Pada 2015, TKSK membuat manajemen pelayanan klien secara menyeluruh. Dilakukan pelaksanaan pengarsipan. Pada 2016TKSK diberi akses untuk dapat berkomunikasi maupun menerima informasi dari Comman Center 112. Yakni, sentral informasi semua keluhan maupun apresiasi dari warga Surabaya. Dikelola oleh Dinas Komunikasi dan Informatika.

Kebijakan ini melibatkan beberapa pemangku kepentingan di internal Pemerintah Kota Surabaya dan pihak eksternal. Jadi, ada sinergitas dalam pelaksanaannya. Sinergitas semacam ini penting untuk menjalankan program atau mengeluarkan inovasi daerah (Najiyati \& Susilo, 2011: Rahmawati, 2014). Wali Kota Surabaya Tri Rismaharini sebagai penggagas program inovasi optimalisasi tugas TKSK 
dengan dukungan fasilitas. Dinas Sosial selaku leading sector dan media komunikasi langsung dengan para TKSK. Dinas Komunikasi dan Informatika (Diskominfo) selaku leading sector Command Center 112. Kelurahan/Kecamatan yang ikut berkoordinasi untuk memecahkan masalah di level akar rumput.

Sumber daya manusia yang terlibat dalam pelaksanaan program ini berasal dari interal Pemerintah Kota Surabaya. Mereka berasal dari Dinas Sosial, Kelurahan/Kecamatan. Mereka bertugas membantu dan memfasilitasi TKSK dalam melaksanakan tugas. Sekaligus, aparat pemerintahan juga bertugas untuk mencarikan solusi dari segala masalah PMKS. Sumber daya atau petugas TKSK adalah elemen masyarakat yang peduli dengan sekitarnya. Di Surabaya, mereka berjumlah 31 orang, sesuai jumlah kecamatan yang ada.

Sumber daya alat yang ada antara lain, Handy Talky yang dimiliki tiap anggota TKSK. Perangkat Command Center 112 yang dimiliki Pemerintah Kota Surabaya untuk mendapatkan laporan atau informasi seputar kota. TKSK memiliki akses untuk mendapat informasi dari sana. Mobil angkut dari Pemerintah Kota untuk membawa PMKS dan bisa digunakan di dalam kota maupun di luar kota. Mobil ambulan Dinas Sosial yang bisa digunakan untuk membawa PMKS dan bisa digunakan di dalam kota sehubungan dengan persoalan kesehatan yang menimpa PMKS. Untuk mendukung program ini, pengadaan alat-alat dibiayai dengan APBD. Sejak tahun 2009, Pemerintah Kota menyalurkan dana-dana untuk memfasilitasi tugas TKSK di semua Kecamatan di Indonesia. 


\section{PENUTUP}

Kemajuan teknologi komunikasi dan informasi mesti dimanfaatkan untuk memaksimalkan pelayanan publik. Pengadaan alat komunikasi dan informasi, termasuk adanya Command Center 112 adalah usaha melakukan pemanfaatan tersebut. Selain itu, untuk optimalisasi layanan, sinergitas antar OPD adalah kebutuhan mutlak yang mesti dipenuhi. Sinergitas Pemerintah Kota dengan elemen masyarakat termasuk TKSK adalah suatu keharusan pula. Terlebih, daya jelajah dan jangkauan TKSK sangat luas. Mereka tidak terikat dengan birokrasi. Mereka adalah relawan murni yang siap berkorban untuk warga Surabaya.

Program Command Center 112 yang terkoneksi dengan TKSK ini bisa dijaga keberlanjutannya. Bahkan, harus dikembangkan sistem manajerialnya. Misalnya, dengan mengembangkan sistem pengarsipan online dan terintegrasi. Sehingga, data riwayat PMKS bisa terpantau dengan maksimal. Optimalisasi tugas TKSK bisa dilakukan di daerah lain. Meskipun, kerap kali, persoalan PMKS di tiap daerah pasti berbeda. Yang jelas, pola penguatan komunikasi dan penyebaran informasi bisa dipakai di mana saja. Apalagi, teknologi saat ini sudah sangat berkembang pesat sehingga dapat digunakan di kawasan mana pun. Khususnya, di Jawa Timur.

Sementara itu, kegiatan TKSK dilakukan setiap hari. Oleh karena itu, monitoring dan evaluasi harian juga dilaksanakan tiap hari. Koordinasi dengan pihak Pemerintah Kota bila terjadi masalah di lapangan juga langsung dilaksanakan saat itu juga. Pertemuan rutin bulanan antara TKSK dan Dinas Sosial untuk mengevaluasi semua kegiatan berikut fasilitas-fasilitas yang ada dilaksanakan secara rutin. Selain itu, tiap tahun, dilakukan pula evaluasi bersama Dewan Perwakilan Rakyat Daerah. 


\section{REFERENSI}

Afifa, Millati, E. L. I. T. Strategi Pelayanan Satu Pintu Dalam Menangani Pengaduan Darurat Oelh Pemerintah Kota Surabaya Melalui Layanan Darurat 112 Command Center. Publika 5.1 (2017).

Anderson, James E. 1984. Public Policy Making. Holt, Rinehart and Wiston. New York.

Arfiadi, Yoyong, and Iman Satyarno. Perbandingan Spektra Desain Beberapa Kota Besar di Indonesia dalam SNI Gempa 2012 dan SNI Gempa 2002 (233S). (2013).

Detik Surabaya, 2017, Apresiasi untuk Pemkot Surabaya dalam Rehabilitasi PMKS. Dapat diakses di https://news.detik.com/berita-jawa-timur/d3700172/apresiasi-untuk-pemkot-surabaya-dalam-rehabilitasi-pmks, diakses pada 24 Juli 2019

Dijkzeul, Dennis \& Moke, Markus. (2005). Public Communication Strategies of International Humanitarian Organizations. Vol. 87, No. 860.

Enciety.Co, 2017, Ini Suka Duka Relawan Tenaga Kesejahteraan Sosial di Surabaya. Dapat diakses di https://www.enciety.co/ini-suka-duka-relawan-tenagakesejahteraan-sosial-di-surabaya/, diakses pada 23 Juli 2019

Irza Chairani Makhdar, A. F. Kualitas Pelayanan Tanggap Darurat Bencana Command Center 112 Di Badan Penanggulangan Bencana Dan Linmas Kota Surabaya. Publika 6.2 (2018).

Najiyati, Sri, and Slamet Rahmat Topo Susilo. Sinergitas instansi pemerintah dalam pembangunan Kota Terpadu Mandiri. Jurnal Ketransmigrasian 28.2 (2011): 113124.

Pramadya, Luki. Implementasi Program Campus Social Responsibility Dinas Sosial Kota Surabaya (Studi Pada Kegiatan Pendampingan Mahasiswa Asuh Terhadap Anak PMKS). Publika 4.2 (2016).

Pranowo and A. Nururrochman Hidayatullah. "Sinergy The Role of Social Welfare Institution Holders through Family Care Unit (FCU)." Jurnal Penelitian Kesejahteraan Sosial 15.4 (2018): 317-328.

Purwantoro, Aswin. Tingkat pengetahuan masyarakat surabaya mengenai sosialisasi command center call 112 (emergency line) melalui media publikasi. Diss. Widya Mandala Catholic University Surabaya, 2019.

Rahmawati, Triana. Sinergitas Stakeholders dalam Inovasi Daerah (Studi pada Program Seminggu di Kota Probolinggo (SEMIPRO)). Jurnal Administrasi Publik 2.4 (2014): 641-647.

Santoso, Eko Budi. Daya Saing Kota-Kota Besar di Indonesia. Makalah. Seminar Nasional Perencanaan Wilayah dan Kota ITS. Surabaya. 2009.

Vinda, Kurnia. Efektivitas Program Pemberdayaan Masyarakat Dalam Kelompok Usaha 
Bersama (Studi Kasus Pada Pemberian Bantuan Mesin Jahit Kelompok Usaha Bersama Bunga Sejahtera Desa Ngampungan Kecamatan Bareng Kabupaten Jombang). Publika 5.1 (2017).

Watie, Errika Dwi Setya. Komunikasi dan media sosial (communications and social media). Jurnal The Messenger 3.2 (2016): 69-74. 